\title{
Development and Mechanical Testing of Carbon Fiber Reinforced Polymer Matrix Composites for Micro Wind Turbine Applications
}

\author{
D.G. Puttaraju* \\ H.G. Hanumantharaju \\ Department of Mechanical Engineering, UVCE Bangalore, India
}

\begin{abstract}
In this century, composites have been discovered to be the most promising and discriminating material accessible. Composites reinforced with synthetic or natural fibres are becoming more popular as demand for light weight, high strength materials for specialized applications grows are on the rise in the market. In the current work Carbon fiber Reinforced Polymer Matrix Composite material is developed aiming wind turbine blade applications. This research demonstrates the successful development of a carbon fibre reinforced Epoxy matrix composite that can be utilized to make micro wind turbine blades and is very cost effective thanks to the utilization of a simple hand lay-up approach. The peak elongation varies from $12.248 \mathrm{~mm}$ to $14.417 \mathrm{~mm}$, and the tensile strength varies from $939.472 \mathrm{~N} / \mathrm{mm} 2$ to $960.910 \mathrm{~N} / \mathrm{mm} 2$. It was observed that the Compressive Strength varies from $8.992 \mathrm{~N} / \mathrm{mm} 2$ to 46.895 $\mathrm{N} / \mathrm{mm} 2$ and peak elongation varies from $1.808 \mathrm{~mm}$ to 3.462 $\mathrm{mm}$. In three-point bending test, the peak load was found to be 509.96 N. Due to the presence of carbon fibre reinforcement, the bending strength of polyester resin has been greatly increased.
\end{abstract}

Keywords: Composite Materials, Micro Wind turbine

\section{Introduction}

The development of new materials with improved strength, stiffness, density and cost-effectiveness has been demanded by the industrial rapid growth [4]. Composite materials have emerged as one of the materials with better properties that may be employed in a variety of applications [13]. A composite material is made up of two or more constituent materials with significantly diverse physical or chemical properties that, when combined, provide a material with distinct qualities from the separate components. The fundamental components remain separate and distinct inside the finished structure. Natural or synthetic fibres are widely used in the fabrication of composite materials in a variety of industries, including construction, mechanical, automotive, aerospace, biomedical and marine [5-6].

Energy consumption has increased as the world's population and civilization have grown. Simultaneously, environmental consciousness has emerged as a serious environmental issue in the global marketplace. Oil, coal, wind, gas, hydro energy and other types of energy are all major sources of energy on the planet [7-10]. The development of the wind energy concept was prompted by an increasing desire to use renewable energy sources. Wind energy is a prominent renewable energy source that can assist in addressing the world's energy issues. Wind turbines or mills have been created to transform the kinetic energy of the wind into mechanical or electrical energy [11]. Wind turbine development for power generation is an exciting promise. One of the most significant components of a wind turbine is the rotor blades [12].

The primary criterion for selecting materials for wind turbine blades is that they must be strong and rigid, have a low density, and have good fatigue strength [13]. The blade's strength must be sufficient to bear the force acting on it without fracture, as well as rigid enough to avoid striking the tower during extreme loading circumstances. For the construction of wind turbine blades, the wind turbine industries are concentrating on the development of low weight, cost-effective, and environmentally friendly materials [12]. The choice of appropriate blade materials is critical in determining the eventual efficiency of a wind turbine blade.

Ganesh R Kalagi et al., [12] The application of natural fibre reinforced polymer composites in wind turbines, as well as the requirements for the composites, their properties, constituents, manufacturing technologies, and defects, are discussed in this research paper. Promising future directions for the composite materials are also discussed. V. García et al., [14] studied the suitability of basalt fibers on wind turbine blade applications using computation techniques. He concluded that, composite materials are an excellent replacement for metals in wind turbine applications. Sharma Set al., [15] studied the suitability of carbon-glass fiber reinforced composites for wind turbine blade applications. The authors concluded that the strength of composite is $160 \%$ higher than the conventional materials. Based on the literature study, it is observed that very less work has been carried out on carbon fiber composites. In the current work Carbon fiber Reinforced Polymer Matrix Composite material is developed aiming wind turbine blade applications.

\section{Experimental Methods and Materials}

This section describes the various materials and apparatus used in the experiment. The procedure for creating composite materials is also outlined.

\subsection{Development of Composite Material}

Hand lay-up technique is used to fabricate the composites at room temperature. This technique has multiple 
advantages and it is also economical for short production and prototype making. In this technique, the required ingredients of epoxy resin LY556 and hardener 951 are thoroughly mixed and the mixture is then constantly agitated in a basin. Carbon fibres are manually placed in the open mould. Carbon fiber lamina is shown in fig 1 . The resulting mixture is brushed evenly over the glass plies. The Vacuum bag is mounted on the open mould as to remove the extra resin that builds up during hand laying process (Fig 2). The bag is pushed by atmospheric pressure. The pressure on the laminate removes trapped air, extra resin and compacts the laminate resulting in a higher fibre reinforcement percentage. Fig. 3 shows the developed composite material.

Table.1: Ingredients of matrix system

\begin{tabular}{|c|c|c|c|}
\hline Ingredients & $\begin{array}{c}\text { Trade } \\
\text { Name }\end{array}$ & Chemical Name & $\begin{array}{c}\text { Density } \\
(\mathbf{g m} / \mathbf{c m 3})\end{array}$ \\
\hline $\begin{array}{c}\text { Epoxy } \\
\text { Resin }\end{array}$ & LY556 & $\begin{array}{c}\text { Diglyodal Either of } \\
\text { Bisphenol A }\end{array}$ & 1.16 \\
\hline Hardener & HY951 & $\begin{array}{c}\text { Tri ethylene tetra } \\
\text { mine }\end{array}$ & 0.95 \\
\hline
\end{tabular}

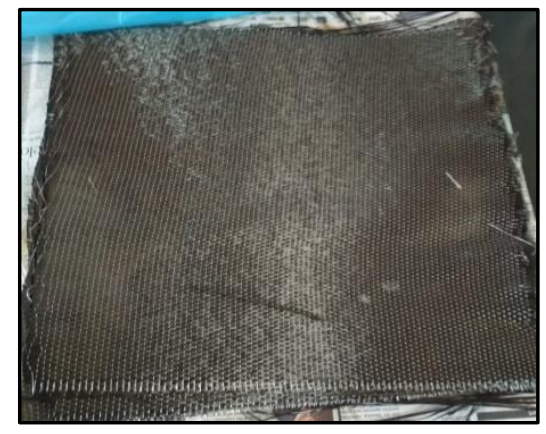

Figure 1: Carbon fiber lamina

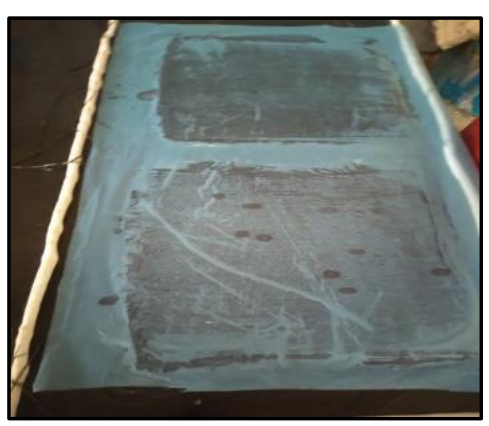

Figure 2: Carbon laminate in vacuum Bag

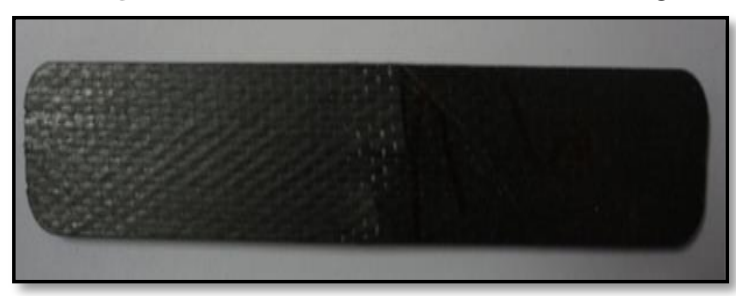

Figure 3: Composite Material

\subsection{Tensile test.}

A UTM is used to perform a tensile test (Universal Testing Machine). The force required to break the composite specimen is measured, as is the distance the specimen extends or elongates to achieve that breaking point. Table 2 lists the parameters for tensile test specimens.

Table 2: Details of tensile test specimen

\begin{tabular}{|l|l|}
\hline Type of test & Tensile \\
\hline Shape & Rectangle(flat) \\
\hline Width & $31.95 \mathrm{~mm}$ \\
\hline Thickness & $3.1 \mathrm{~mm}$ \\
\hline
\end{tabular}

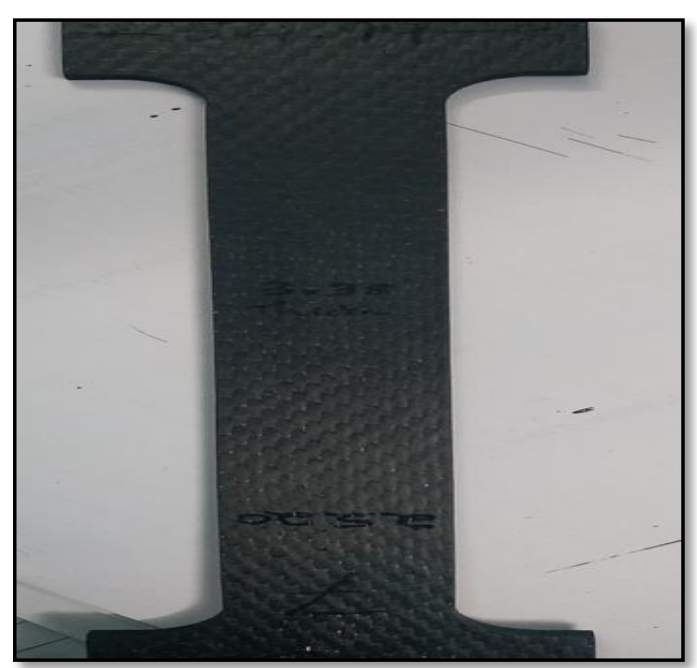

Figure 4: Tensile Test Specimen

Table 3. Lay Up and Orientation

\begin{tabular}{|c|c|c|c|c|c|c|c|c|c|c|}
\hline $1^{\text {st layer (top layer) - UNIDIRECTIONAL fibres }}$ & 0 & & $d$ & 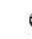 & & $g$ & & & $\mathrm{e}$ & e \\
\hline $2^{\text {nd }}$ layer - UNIDIRECTIONAL fibres & 0 & & $d$ & & & g & & & e & e \\
\hline $3^{\text {rd }}$ layer - UNIDIRECTIONAL fibres & + & 4 & 5 & $d$ & $\mathrm{e}$ & & & $\mathrm{r}$ & e & e \\
\hline $4^{\text {th }}$ layer - UNIDIRECTIONAL fibres & - & 4 & 5 & & & & 8 & $\mathrm{r}$ & e & e \\
\hline $5^{\text {th }}$ layer - UNIDIRECTIONAL fibres & - & 4 & 5 & & & & $g$ & 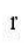 & e & e \\
\hline 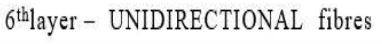 & + & 4 & 5 & & & & $\mathrm{~g}$ & & $\mathrm{e}$ & e \\
\hline $7^{\text {th }}$ layer - UNIDIRECTIONAL fibres & 9 & 0 & & d & , & & & & e & e \\
\hline $8^{\text {th }}$ layer(bottom layer) - UNIDIRECTIONAL fibres & 9 & 0 & & $d$ & 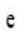 & & & r & e & $e$ \\
\hline
\end{tabular}

The specimen used for the tensile test is having 6 layer of carbon fiber reinforced composite lamina having zero degree orientations. The dimensions used for the preparation of tensile test specimen are $250 \mathrm{~mm}$ length $\mathrm{x} 25 \mathrm{~mm}$ width $\mathrm{x} 3.30 \mathrm{~mm}$ thick. The layup orientation for tensile test specimen is shown in table 3. The developed specimen for tensile testing is shown in Fig 4. 


\subsection{Compression test.}

After removing the created composite specimens from the mould, specimens of compression test appropriate dimensions were prepared in accordance with ASTM requirements. A water jet cutting equipment was used to cut the test specimens. Figure 5 depicts the dimensions utilized in the production of compression test specimen. The compression strength is measured using a universal testing machine (UTM). A rectangular cross-section bar is attached to a wedge clip and loaded by moving the cross head. Deflect the specimen until it ruptures or a maximum strain of 5 percent is attained, whichever comes first. Three test specimens are subjected to compression testing. The findings of the tests are discussed in detail in the next section. Fig 6. Shows the developed compression test specimen.

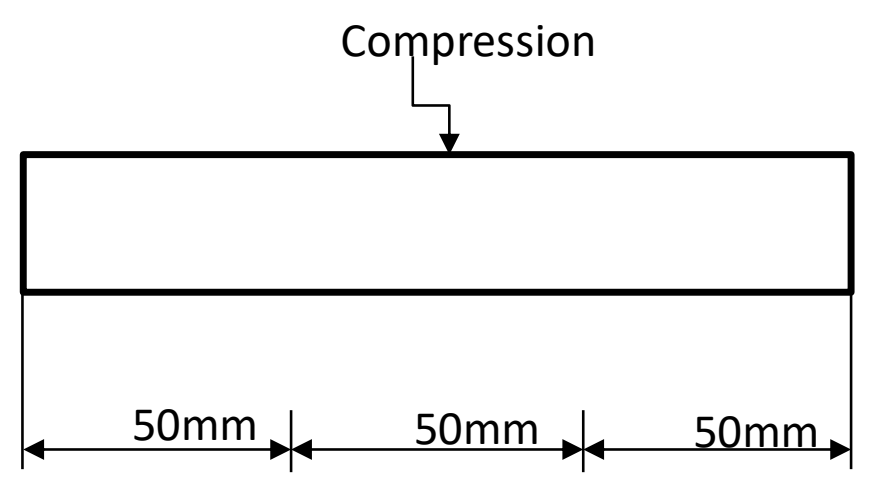

Figure 5: Compression test specimen dimensions.

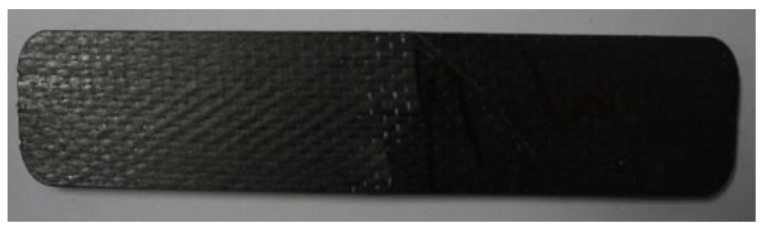

Figure 6: Compression test specimen.

\subsection{Bending test.}

The flexural test setup is shown in Figure 8. Flexural strength refers to a material's capacity to resist deformation under load. It's a three-point bend test that results in interlaminar shear failure most of the time. According to ASTM D790, this test is performed with UTM. This information is typically utilised to make decisions about the materials to employ for various parts that must support loads without flexing. Bending test specimen and its dimensions are shown in Fig 6 and 7 respectively.

\section{Results and Discussions}

In the current study, carbon Fiber Reinforced Polymer Matrix Composite material is developed with an intention of micro wind turbine application. The developed composite material is subjected to Mechanical characterization. The properties like tensile strength, Compression strength and flexural strength are determined and presented. Each test is repeated two times to ensure uniformity.

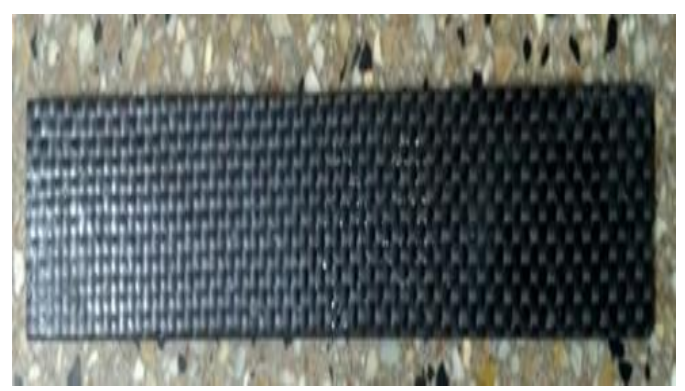

Figure 7: Three point bending test specimen

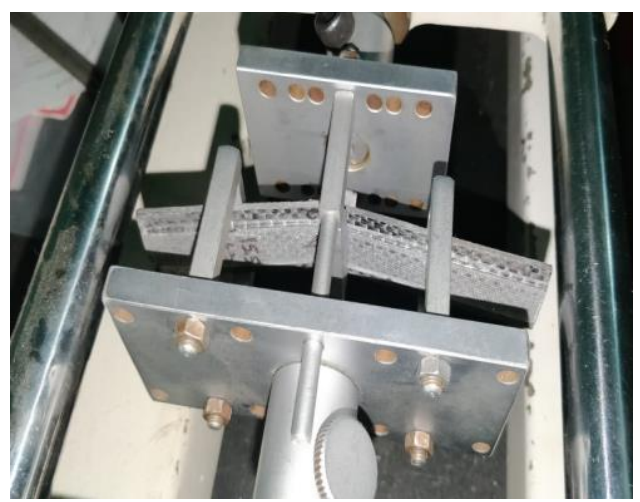

Figure 8: Three point bending test

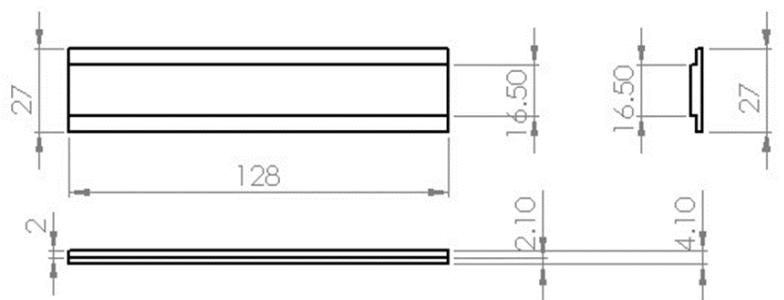

Figure 9: Bending test specimen dimensions.

\subsection{Tensile Strength}

Results obtained from the tensile test are presented in this section. The result from the test is shown in the table 4 and figure 10 and 11 shows the tensile test results of two different specimens of same type. Two specimens are tested at the time to ensure repeatability and accuracy of the results. Carbon fibre reinforced composites have a greater ultimate tensile strength because carbon fibre has a higher strength and behaves like an elastic material under tensile loading. The use of carbon fibre mat reinforced polymeric composite greatly increased the composite's ultimate tensile strength.

In case of specimen 1, the peak load was observed to be $95.08 \mathrm{kN}$ and elongation at peak load was $14.417 \mathrm{~mm}$ and corresponding tensile strength was found to be $960.910 \mathrm{~N} / \mathrm{mm} 2$. In case of specimen 2, the peak load was observed to be 93.05 $\mathrm{kN}$ and elongation at peak load was $12.248 \mathrm{~mm}$ and corresponding tensile strength was found to be $939.472 \mathrm{~N} / \mathrm{mm} 2$. 


\section{International Journal of Scientific Research in Engineering and Management (IJSREM)}

The maximum variation in peak load was found to be $2.13 \%$ between the two specimens. In case of elongation the variation was found to be $15.04 \%$ and in case of tensile strength it was found to be $2.23 \%$. Fig 12 shows the tensile test specimens after deformation.

Graphs describes typical load vs. deflection of the specimens. Curves for the specimens show linear behaviour until failure.

Table 4: Result from Tensile Testing

\begin{tabular}{|c|c|c|c|c|c|c|}
\hline $\begin{array}{c}\text { Spec } \\
\text { imen } \\
\text { No. }\end{array}$ & $\begin{array}{c}\text { Thick } \\
\text { ness } \\
(\mathrm{mm})\end{array}$ & $\begin{array}{c}\text { Width } \\
(\mathrm{mm})\end{array}$ & $\begin{array}{c}\text { Peak } \\
\text { Load } \\
(\mathrm{kN})\end{array}$ & $\begin{array}{c}\text { Elongation } \\
\text { at Peak } \\
(\mathrm{mm})\end{array}$ & $\begin{array}{c}\text { Tensile } \\
\text { Strengt } \\
\mathrm{h} \\
\mathrm{N} / \mathrm{mm}^{2}\end{array}$ & $\begin{array}{c}\text { Break } \\
\text { load } \\
(\mathrm{kN})\end{array}$ \\
\hline 1 & 3.1 & 31.92 & 95.08 & 14.417 & 960.91 & 95.08 \\
\hline 2 & 3.1 & 31.95 & 93.05 & 12.248 & 939.47 & 93.05 \\
\hline
\end{tabular}

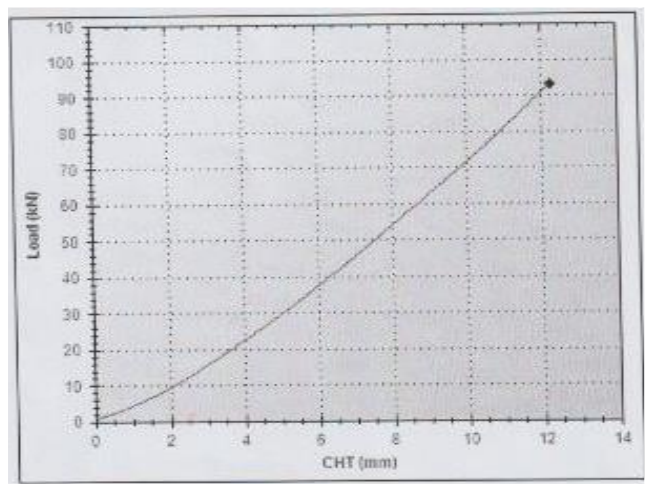

Fig 10: Tensile strength for specimen 1

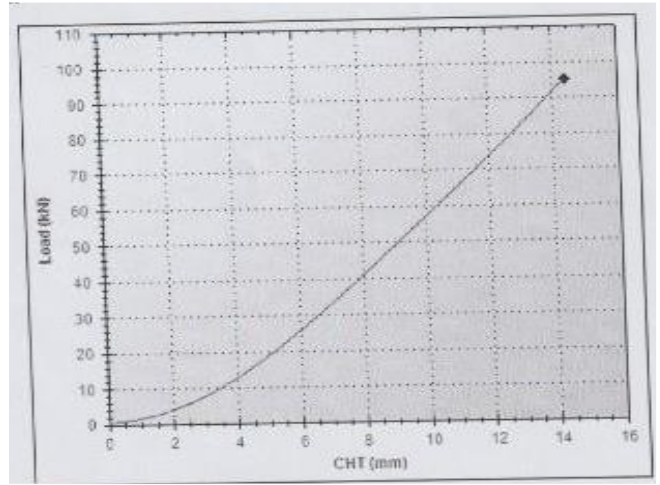

Fig 11: Tensile strength for specimen 2

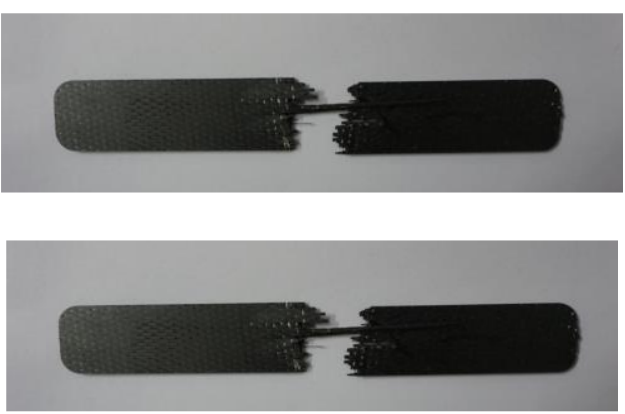

Fig 12: Tensile specimens after test

\subsection{Compression Strength}

Table 5: Result from compression Testing

\begin{tabular}{|c|c|c|c|c|c|c|c|}
\hline $\begin{array}{c}\text { Spec } \\
\text { imen } \\
\text { No. }\end{array}$ & $\begin{array}{c}\text { Thickne } \\
\text { ss }(\mathrm{mm})\end{array}$ & $\begin{array}{c}\text { Widt } \\
\mathrm{h} \\
(\mathrm{mm})\end{array}$ & $\begin{array}{c}\text { Peak } \\
\text { Load } \\
(\mathrm{N})\end{array}$ & $\begin{array}{c}\text { Elongat } \\
\text { ion at } \\
\text { Peak } \\
(\mathrm{mm})\end{array}$ & $\begin{array}{c}\text { Compres } \\
\text { sive } \\
\text { Strength } \\
\left(\mathrm{N} / \mathrm{mm}^{2}\right)\end{array}$ & $\begin{array}{c}\text { Strai } \\
\mathrm{n}\end{array}$ & $\begin{array}{c}\text { Break } \\
\text { load } \\
(\mathrm{N})\end{array}$ \\
\hline 1 & 3.580 & 25.15 & 4138.6 & 1.892 & 45.965 & 0.024 & 980.7 \\
\hline 2 & 3.670 & 25.04 & 4079.7 & 1.986 & 44.394 & 0.027 & 980.7 \\
\hline
\end{tabular}

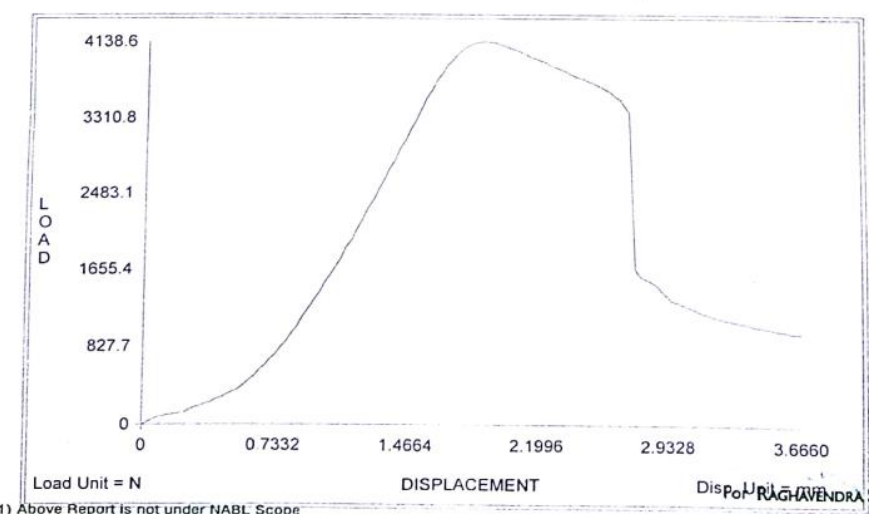

Fig 13: Compression strength for specimen 1

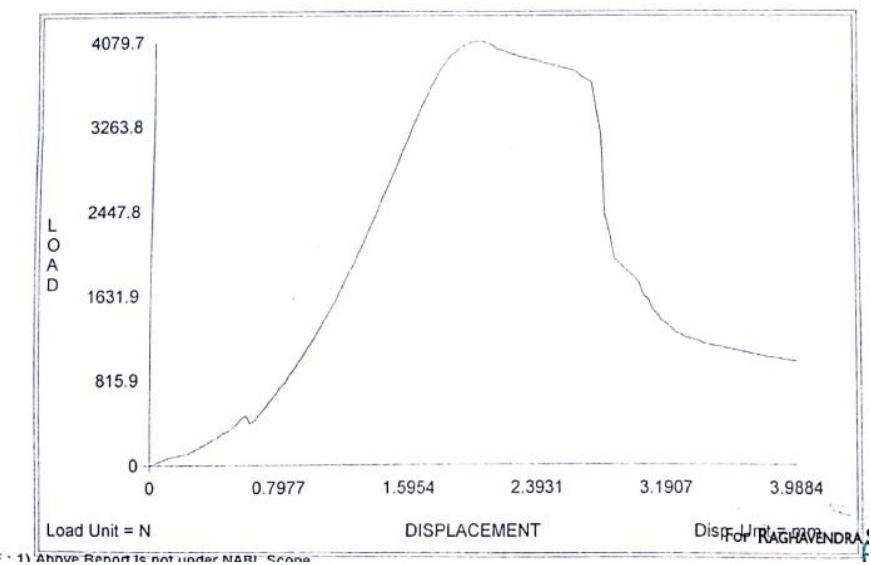

Fig 14: Compression strength for specimen 2
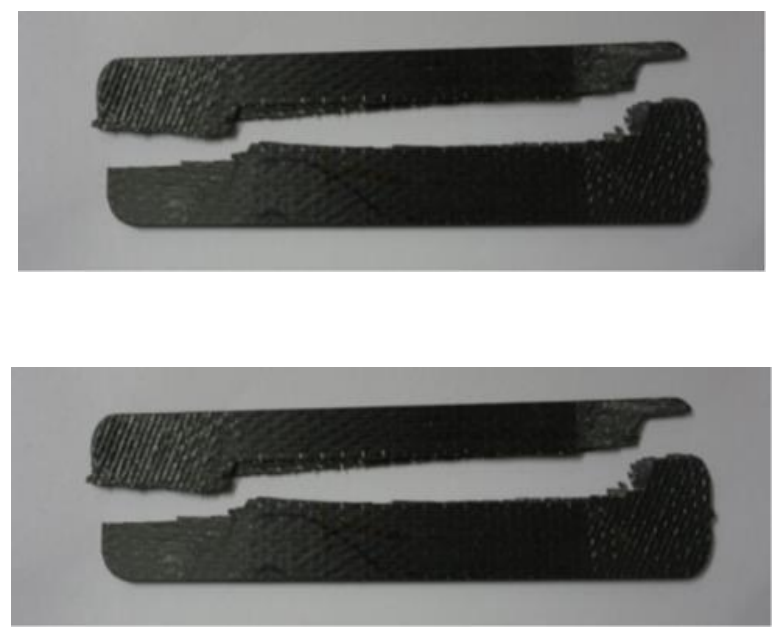

Fig 15: Specimens after test. 
In this section, the results of the compression test are reported. Table 5, Figures 13 and 14, and Table 5 illustrate the results of the test. Figure 15 depicts the specimen following the compression test. Carbon fibre reinforced composites have a higher compressive strength because carbon fibre has a higher strength and behaves like an elastic material when loaded. The use of carbon fibre mat reinforced polymeric composite increased the composite's compressive strength substantially.

In case of specimen 1 , the peak load was observed to be $4.138 \mathrm{kN}$ and elongation at peak load was $1.892 \mathrm{~mm}$ and corresponding compression strength was found to be 45.965 $\mathrm{N} / \mathrm{mm} 2$. In case of specimen 2, the peak load was observed to be $4.079 \mathrm{kN}$ and elongation at peak load was $1.986 \mathrm{~mm}$ and corresponding compression strength was found to be 44.394 $\mathrm{N} / \mathrm{mm} 2$. The maximum variation in peak load was found to be $1.423 \%$ between the two specimens. In case of elongation the variation was found to be $4.73 \%$ and in case of compression strength it was found to be $3.41 \%$. Graphs describes typical load vs. deflection of the specimens. Curves for the specimens show linear behaviour until peak load.

\subsubsection{Bending Test}

Table 6: Result from Bending Test

\begin{tabular}{|c|c|c|c|c|c|c|}
\hline $\begin{array}{c}\text { Spec } \\
\text { imen }\end{array}$ & $\begin{array}{c}\text { Thickn } \\
\text { ess (in } \\
\text { mm) }\end{array}$ & $\begin{array}{c}\text { Peak } \\
\text { load } \\
\text { (in N) }\end{array}$ & $\begin{array}{c}\text { Peak } \\
\text { Displace } \\
\text { ment } \\
\text { (in mm) }\end{array}$ & $\begin{array}{c}\text { Break load } \\
\text { (in N) }\end{array}$ & $\begin{array}{c}\text { Break } \\
\text { Displace } \\
\text { ment } \\
\text { (in mm) }\end{array}$ & $\begin{array}{c}\text { Strai } \\
\mathrm{n}\end{array}$ \\
\hline 1 & 4.030 & 1098.4 & 1.570 & 509.96 & 4.854 & 0.08 \\
\hline
\end{tabular}

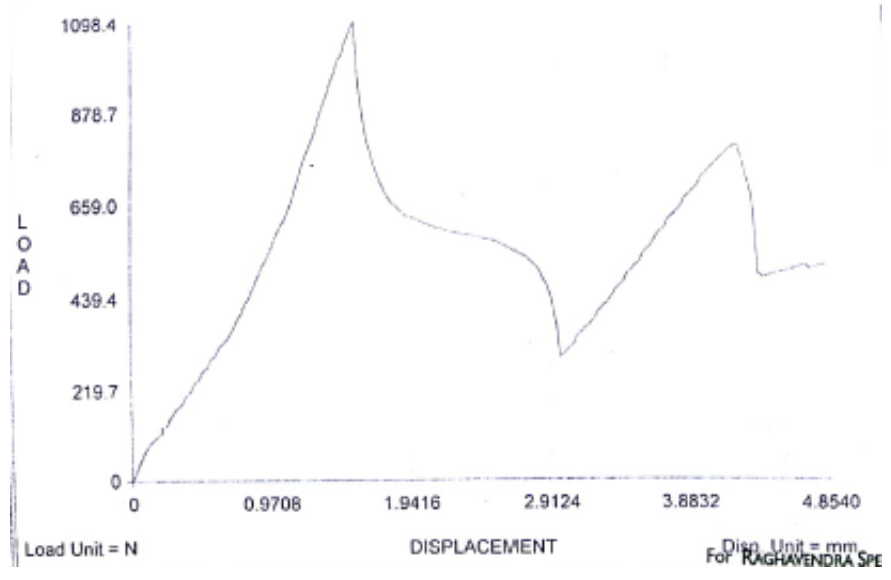

Fig 16: Bending test Result

Table 6 and fig 16 present the results of this experimental effort. The mechanical properties of carbon fiber-reinforced epoxy composites are determined by the constituent materials' properties (type, quantity, fibre distribution and orientation, void content). Three elements determine the resulting flexural strength of a specimen during the three point bending test: the matrix's flexural strength, the adhesion between fibres and matrix, and hence the adhesion between laminates. The values obtained have been analysed from available literature and an excellent agreement between test results has been observed. In case of bending test, the peak load was observed to be $1,098 \mathrm{kN}$ and elongation at peak load was $1.570 \mathrm{~mm}$ and corresponding Break Displacement was found to be $4.854 \mathrm{~mm}$. The strain at beak load was found to be 0.081 . Fig 17 shows the specimen after test.

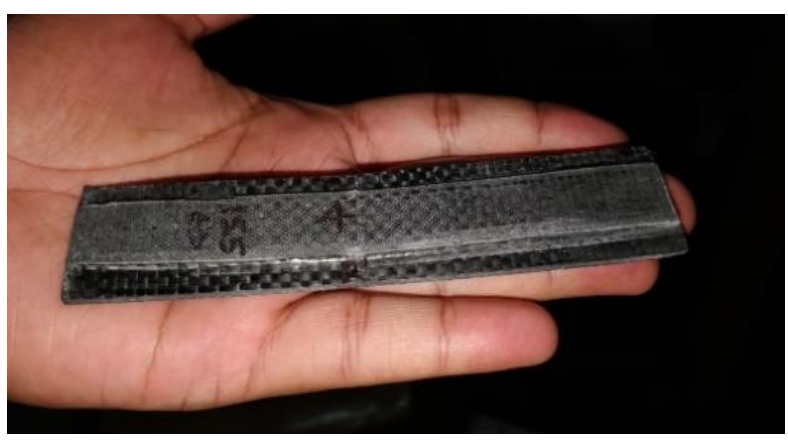

Fig 17: Specimens after test

\section{Conclusions}

In this study, carbon fibre reinforced composite specimens were developed using the vacuum bag method, and experimental evaluation of mechanical properties such as tensile, compression and bending tests of carbon fibre composites were successfully conducted according to ASTM standards. The following results are drawn from this experimental study of the mechanical behaviour of carbon fibre reinforced epoxy matrix composites:

- This research demonstrates the successful development of a carbon fibre reinforced Epoxy matrix composite that can be utilised to make micro wind turbine blades and is very cost effective thanks to the utilisation of a simple hand lay-up approach.

- The peak elongation varies from $12.248 \mathrm{~mm}$ to 14.417 $\mathrm{mm}$, and the tensile strength varies from 939.472 $\mathrm{N} / \mathrm{mm} 2$ to $960.910 \mathrm{~N} / \mathrm{mm} 2$.

- It was observed that the Compressive Strength varies from $8.992 \mathrm{~N} / \mathrm{mm} 2$ to $46.895 \mathrm{~N} / \mathrm{mm} 2$ and peak elongation varies from $1.808 \mathrm{~mm}$ to $3.462 \mathrm{~mm}$.

- In three-point bending test, the peak load was found to be $509.96 \mathrm{~N}$. Due to the presence of carbon fibre reinforcement, the bending strength of polyester resin has been greatly increased.

\section{REFERENCES}

[1] T.G. Yashas Gowda, M.R. Sanjay, K. Subrahmanya Bhat, P. Madhu, P. Senthamaraikannan \& B. Yogesha "Polymer matrixnatural fiber composites: An overview", Cogent Engineering, 5:1, DOI: 10.1080/23311916.2018.1446667.

[2] Sherif G, Chukov D, Tcherdyntsev V, Torokhov V. Effect of Formation Route on the Mechanical Properties of the Polyethersulfone Composites Reinforced with Glass Fibers. 
Polymers (Basel). 2019; 11 (8):1364. Published 2019 Aug 19. DOI: $10.3390 /$ polym11081364.

[3] Naveena H S, Sunil S, Shrishail Kakkeri \& Suresh R (2021) Development and mechanical testing of natural fibre reinforced polypropylene resin hybrid composite, Advances in Materials and Processing Technologies, DOI: 10.1080/2374068X.2021.1948704.

[4] M. Devendra Reddy, S. Sunil, B.S. Chandra Prasad, Shrishail Kakkeri, Studies on alternative hybrid materials for replacement of R134a in space heating process, Materials Today: Proceedings, Volume 44, Part 1, 2021,Pages 716-721,

[5] Zagho, M.M.; Hussein, E.A.; Elzatahry, A.A. Recent Overviews in Functional Polymer Composites for Biomedical Applications. Polymers 2018, 10, 739. https://doi.org/10.3390/polym10070739.

[6] Neves Monteiro, S.; Salgado de Assis, F.; Ferreira, C.L.; Tonini Simonassi, N.; Pondé Weber, R.; Souza Oliveira, M.; Colorado, H.A.; Camposo Pereira, A. Fique Fabric: A Promising Reinforcement for Polymer Composites. Polymers 2018, 10, 246. https://doi.org/10.3390/polym10030246.

[7] S. Sunil, B.S. Chandra Prasad, M. Kotresh, Shrishail Kakkeri, Studies on suitability of multiwalled CNT as catalyst in combustion on a $\mathrm{CI}$ engine fueled with dairy waste biodiesel blends, Materials Today: Proceedings, Volume 26, Part 2, 2020, Pages 613-619, https://doi.org/10.1016/j.matpr.2019.12.179.

[8] S. Sunil, B.S. Chandra Prasad, Shrishail Kakkeri, Suresha, "Studies on titanium oxide nanoparticles as fuel additive for improving performance and combustion parameters of CI engine fueled with biodiesel blends, Materials Today: Proceedings, Volume 44, Part 1, 2021, Pages 489-499.

[9] Anjaneya G, Udaya Ravi M, Sunil S, Prabhakar Reddy C, "Performance optimization of air cooled diesel engine with simarouba biodiesel blends as substitute fuel using response surface method", Petroleum Science and Engineering, Science Publishing Group, 1(1):22-28,2 2016. 1.

[10] Sunil S., Kakkeri S., Chandra Prasad B.S., Kapilan N., Shivarudraiah (2021) Feasibility Studies on Spent Coffee Powder Oil as Alternative to Diesel in CI Engines. In: Arockiarajan A., Duraiselvam M., Raju R. (eds) Advances in Industrial Automation and Smart Manufacturing. Lecture Notes in Mechanical Engineering. Springer, Singapore. https://doi.org/10.1007/978981-15-4739-3_78.

[11] Olusegun David Samuel and Stephen "Assessing Mechanical Properties of Natural Fibre Reinforced Composites for Engineering Applications" Journal of Minerals and Materials Characterization and Engineering, 2012, 11, 780-784

[12] Ganesh R Kalagi, Rajashekar Patila, Narayan Nayaka "Experimental Study on Mechanical Properties of Natural Fiber Reinforced Polymer Composite Materials for Wind Turbine Blades" Materials Today: Proceedings 5 (2018) 2588-2596.

[13] Bénard Q, Fois M, Grisel M. Roughness and fibre reinforcement effect onto wettability of composite surfaces. Appl Surf Sci 2007;253(10):4753-8.

[14] V. García, L. Vargas, A. Acuña, J. B. Sosa, E. Durazo, R. Ballesteros, J. Ocampo, "Evaluation of Basalt Fibers on Wind Turbine Blades through Finite Element Analysis", Advances in Materials Science and Engineering, vol. 2019, Article ID 1536925, 12 pages, 2019. https://doi.org/10.1155/2019/1536925.

[15] Sharma S, Wetzel KK. Process Development Issues of GlassCarbon Hybrid-reinforced Polymer Composite Wind Turbine Blades. Journal of Composite Materials. 2010; 44(4):437-456. doi:10.1177/0021998309347569. 